Ambiente \& Água - An Interdisciplinary Journal of Applied Science
ISSN 1980-993X - doi:10.4136/1980-993X
www.ambi-agua.net
E-mail: ambi.agua@gmail.com

\title{
Mapping the Available Water Capacity in tropical climate soils for soybean (Glycine max) cultivation in the state of Tocantins-Brazil
}

\author{
ARTICLES doi:10.4136/ambi-agua.2718
}

Received: 06 Mar. 2021; Accepted: 16 Jul. 2021

\begin{abstract}
André de Moura Andrade ${ }^{*(\mathbb{D})}$; Rui da Silva Andrade ${ }^{2}$; Erich Collicchio $^{3(\mathbb{D}}$
${ }^{1}$ Mestrado em Agroenergia. Universidade Federal do Tocantins (UFT), Avenida NS 15, Quadra 109 Norte, CEP: 77001-090, ALCNO-14, Bloco Bala II, Plano Diretor Norte, Palmas, TO, Brazil.

${ }^{2}$ Departamento de Engenharia Ambiental. Universidade Federal do Tocantins (UFT), Avenida

NS 15, Quadra 109 Norte, CEP: 77001-090, ALCNO-14, Bloco Bala II, Plano Diretor Norte, Palmas, TO,

Brazil. E-mail: andradersilva@uft.edu.br

${ }^{3}$ Programa de Pós-Graduação em Agroenergia. Universidade Federal do Tocantins (UFT), Avenida NS 15, Quadra 109 Norte, CEP: 77001-090, ALCNO-14, Bloco Bala II, Plano Diretor Norte, Palmas, TO, Brazil.

E-mail: ecollicchio@uft.edu.br

*Corresponding author. E-mail: andrema@uft.edu.br
\end{abstract}

\begin{abstract}
Brazilian soybean has undergone considerable economic growth. Its production depends on the demand for some inputs. One of these inputs is the soil water supply, which can be made artificially or obtained by natural rainfall. Knowledge of available water capacity (AWC), which depends on total water availability (TWA), is poorly accessible and difficult to measure in the field. This study aimed to map the AWC of the state of Tocantins, based on pedotransfer functions (PTFs), to evaluate the water availability of the soils of the microregions of that state. We used the Arya and Paris model, aided by a computer program, Qualisolo, made by Embrapa Instrumentação. One hundred fifty-seven tropical soil samples were extracted from the Embrapa Solos portal. Preliminarily, the soil water retention curve (SWRC) was obtained and, subsequently, the TWA and AWC for this oilseed were estimated. Multiple linear regressions show the correlation between TWA and clay (CL), Silt (ST) and total sand (TS) contents. The correlation established was TWA $=3.2993-0.0028 \mathrm{TS}-0.0034 \mathrm{CL}$. This main conclusion reflects a fruitful AWC for decision-making by the soybean agribusiness and exposes the regional weaknesses for this crop under a rainfed regime in some regions of Tocantins. We could observe that, in terms of water availability, agribusiness is a potential threat to the environment protection area (APA) of the Ilha do Bananal/Cantão, Formoso River microregion.
\end{abstract}

Keywords: available water capacity, conservation units, pedotransfer.

\section{Espacialização da capacidade de água disponível em solos tropicais om cultura soja (Glycine max) no Estado do Tocantins-Brasil}

\section{RESUMO}

A soja brasileira tem crescido consideravelmente em termos econômicos. Sua produção depende da demanda de alguns insumos. Um desses insumos é o suprimento de água pelo solo, que pode ser feito artificialmente ou obtido pela pluviometria natural. O conhecimento da capacidade de água disponível (CAD), que depende da disponibilidade total de água (DTA), é pouco acessível e de difícil medição e aferição no campo. Esse trabalho teve o objetivo de 
mapear a CAD do Estado do Tocantins, a partir de funções de pedotransferência (FTPs), para fins de se avaliar a disponibilidade hídrica dos solos das microrregiões desse estado. O modelo utilizado foi o de Arya \& Paris com auxílio de um programa de computador, Qualisolo, confeccionado pela EMBRAPA Instrumentação. 157 amostras de solos tropicais foram extraídas do portal da EMBRAPA Solos. Preliminarmente, obteve-se a curva característica de retenção de água (CRA) e, ulteriormente, estimou-se a DTA e a CAD para essa oleaginosa. Por regressões lineares múltiplas fez-se a correlação entre a DTA e os teores de argila (Ag), Silte (Si), areia total (AT) e carbono orgânico (CO). A correlação selecionada devido à sua simplicidade foi DTA = 3,2993 - 0,0028AT - 0,0034Ag. Esta principal conclusão reflete uma CAD profícua para tomadas de decisão por parte da agroindústria da soja e expõe as fragilidades regionais para esta cultura sob regime de sequeiro em algumas regiões tocantinenses. Observouse uma possível ameaça do agronegócio a APA da Ilha do Bananal/Cantão, microrregião do Rio Formoso, que aparece em termos de disponibilidade hídrica.

Palavras-chave: água disponível, pedotransferência, unidades de conservação.

\section{INTRODUCTION}

Production chains tend to adapt to the growing demands for energy resources, which inevitably implies sustainably expanding their production systems. One of the criteria expected for rural expansion is the search for environmental compartments that parameterise low-risk climatic conditions and physical factors favourable to their productive performance (Santos and Martins, 2016).

Among these various agribusiness segments, soybean farming stands out, an energy crop with a more significant market predominance due to the manufacture of biodiesel, cosmetics, food, fertilisers, animal nutrition, among other industrial destinations (Lemos et al., 2017).

The production of soybeans at their reproductive stage, from flowering to filling of the grains, is highly dependent on soil water availability. It is estimated that variations in those stages of development induce fluctuations proportional to yields in different harvest years (Morando et al., 2014).

Water deficiency can affect some physiological aspects of the plant, such as its leaf area indices, metabolism, and photosynthetic performance and shortening plant life cycles (Zanon et al., 2018). Grain quality, the difference between oil and protein contents, can also be affected by this variation in available water, which is not currently desirable when the focus is on increasing biofuel generation (Lima et al., 2017).

The soil water retention curve (SWRC) has been widely used for different management practices in crops in general. The SWRC is a hydraulic property of the soil, and its graphical representation is made by associating the water content in volume $(U)$ retained by the soil to its retention energy represented by the modulus of soil water tension (h). Van Genuchten's (1980) is one of the most widely used models in soil science.

The procedures to obtain SWRC at the field level are costly and time-consuming, require much work and have significant spatiotemporal variability. To overcome these difficulties, we bring the pedotransfer functions (PTFs) concept, which describes the physical relationships between soil attributes (soil and particle densities, particle size distribution and organic matter), which are easy to determine, and the hydraulic properties of soils, such as volumetric humidities, the corresponding matric potential and soil saturated hydraulic conductivity, which are complex measurements, at the laboratory or field level (Prevedello and Armindo, 2015). The PTFs are empirical and mathematical.

However, several PTFs have been created in different climatological contexts over the last few years to estimate the parameters of the SWRC. Because of this, some authors noticed 
inconsistencies between saturation humidities, for example, obtained from the relationships constructed from data from temperate regions. Statistical dispersions and root mean square errors were observed, relatively lower between the sampled and predicted values when using SWRCs from tropical environments. Therefore, the SWRC behaves very differently in different climatic zones, reflecting the choice for PTFs. The minimum requirement is that they should be applied only in areas of interest of the same textural domain of their conception (Tomasella $e t$ al., 2000).

Another way to achieve the hydraulic function of soil WRC is through computer programs. Qualisolo was developed by Instrumentação (http://www.cnpdia.Embrapa.br/downloads/qualisolo/), and is useful in obtaining the graphical forms of soil particle-size distribution, in modelling the SWRC, in obtaining unsaturated hydraulic conductivity and moisture ranges practised in the management of irrigated crops or rainfed areas. This software uses the semi-empirical Arya-Paris method, tested and validated by Vaz et al. (2004) for soils in the state of São Paulo, using the similarity between the sigmoidal curves of soil particle size distribution and water retention of that soil, which validates its use in tropical soils. Their input data can be summarised as Clay (CL), Silt (ST), Total Sand (TS) and Organic Carbon (OC) contents and soil or global (Ds) and particle (Dp) densities.

The overall soil density (Ds), which is easier to obtain at laboratory level, expresses the relationship between the dry soil mass and the total or apparent volume given by the conglomerate formed by solids, water, and air. Particle density Dp refers to the volume effectively occupied by solid matter, disregarding soil porosity (Viana et al., 2017).

SWRC can be exploited for estimates of available water (AW), available water capacity (AWC), and aeration porosity in soils of different textures. AW, and consequently AWC, require other soil characteristics, also difficult to measure at the field level, which are the field capacity $\left(l_{c c}\right)$ and permanent wilting point $\left(\left(_{\mathrm{pmp}}\right)\right.$, both commonly based on volume.

The difficulty in obtaining information on the ideal water for soybean cultivation can be overcome by using pedotransfer equations or functions (PTFs). PTFs are used when the unfeasibility of the cost of laboratory execution in short-term projects is perceived (Prevedello, 2015).

This study recognises the few records of technical data of physical and hydraulic characteristics of the soils that make up a Brazilian macroregion, called Matopiba, whose initials refer to the part of areas of the states of Maranhão (MA), Piauí (PI), Bahia (BA) and the entire area of the state of Tocantins (TO). This region is poor in soil density $\left(\mathrm{D}_{\mathrm{s}}\right)$, particle density $\left(D_{p}\right)$ and organic carbon $(\mathrm{OC})$ or organic matter data, and there are no studies on some characteristics of its soils, such as field capacity $\left({ }_{c c}\right)$ and permanent wilting point $\left({ }_{\mathrm{pmp}}\right)$.

The primary objective of this study was to map the AWC for soybean cultivation in the state of Tocantins based on PTFs that considered TWA as a dependent variable and Clay (CL), Silt (ST), Total Sand (TS) and organic carbon (OC) fractions as independent variables, extracted in spreadsheets of Embrapa Solos portal (Embrapa, 2020).

\section{MATERIALS AND METHODS}

The study area is the federal unit of Tocantins, which is located southeast of the great North region of the country, defined between latitudes $05^{\circ} 10^{\prime}$ and $06^{\prime \prime}$ and $13^{\circ} 27^{\prime}$ and $69^{\prime \prime}$ and longitudes $45^{\circ} 41^{\prime} 46^{\prime \prime}$ and $50^{\circ} 44^{\prime} 33^{\prime \prime}$. According to the pedological survey made available by the updating base of the State Planning Secretariat - Seplan (Tocantins, 2012), the state of Tocantins is composed mostly of Plinthosols (about $35 \%$ of its territory). The state of Tocantins is dominated by the Cerrado biome and is entirely in the Matopiba region. Its federative unit, its main Conservation Units and its microregions are illustrated by Figure 1.

Initially, the source code of the Qualisolo program developed by Embrapa and available to the 
scientific community was reworked through the Python language. Its interface was not used for this discussion, only its method of adjusting the water retention characteristic curve (SWRC) of van Genuchten (1980) by an iterative routine and through the physical-hydric Arya and Paris model (1981).
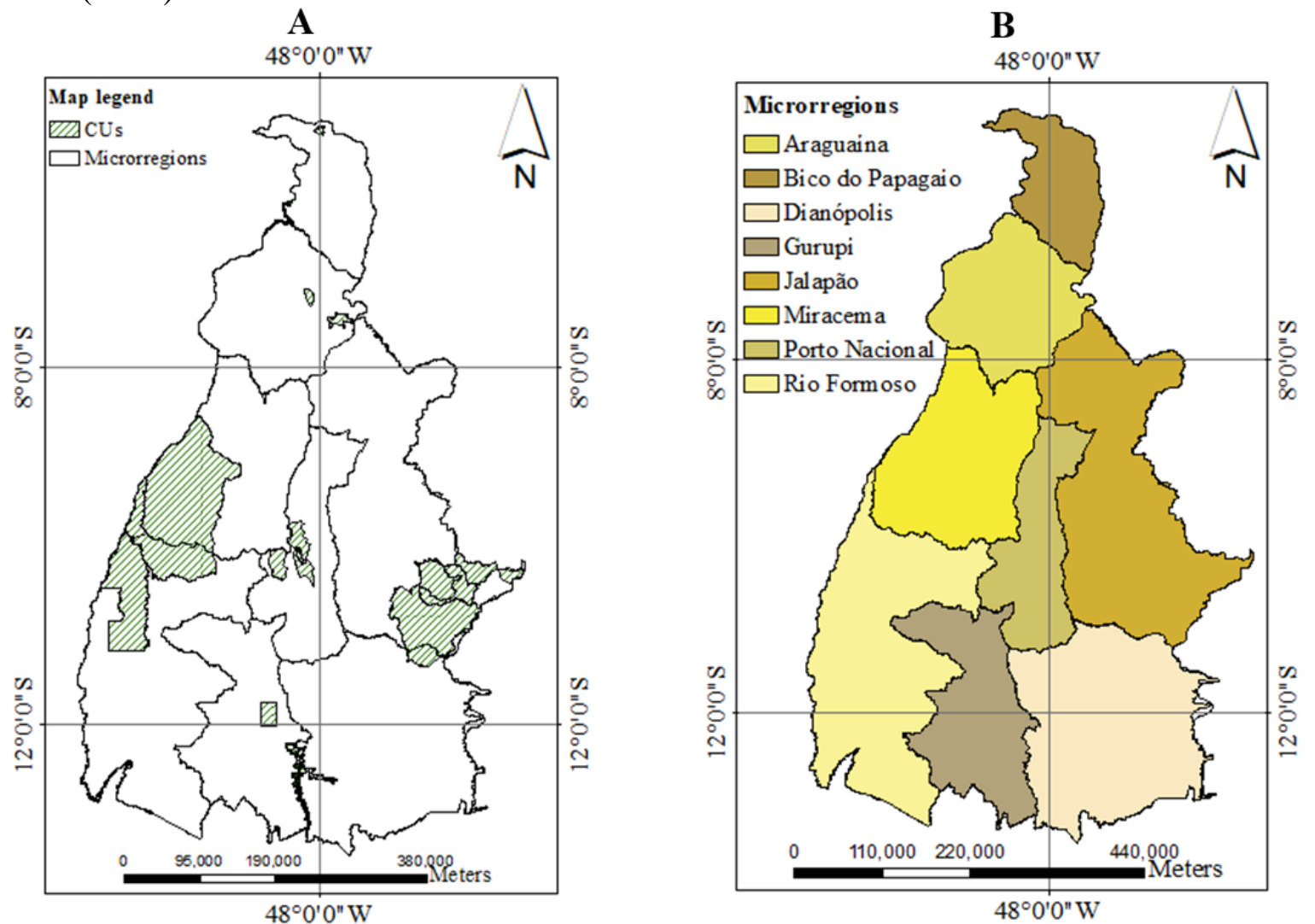

Figure 1. Main Conservation Units (A) and microregions (B) of Tocantins.

The program has been optimised to process various soil samples. For each of these inputs, the Equation 1 by van Genuchten (1980) was adjusted according to the algorithmic routine used for the indirect estimation of the SWRCs (Bruning et al., 2019).

$\theta=(\theta s-\theta r)\left[1+(\alpha h)^{n}\right]^{-m}+\theta_{r}$

Where: $\alpha, \mathrm{n}$, and $\mathrm{m}$ are form parameters of the SWRC; $\theta_{\mathrm{r}}$ and $\theta_{\mathrm{s}}$ are the residual moisture and saturation in $\mathrm{m} 3 \mathrm{~m}-3$ and $\mathrm{h}$ is the modulus of the independent variable of the soil matric potential, given in $\mathrm{hPa}$.

Through Embrapa's Brazilian Soil Information System platform (Embrapa, 2018), particle size tests of 327 points were collected in the states that compose Matopiba. Of these experiments, only 157 had soil bulk density $\left(D_{s}\right)$ data in $\mathrm{kg} \mathrm{m}-3$ and particle density $\left(\mathrm{D}_{\mathrm{p}}\right)$ data in $\mathrm{kg} \mathrm{m}-3$. For the latter samples, the coefficients of the SWRC were determined. TWA quantification is given by Equation 2 .

$$
T W A=10\left(\theta_{F C}-\theta_{W P}\right)
$$

Where: TWA is the total water availability in the soil (in $\mathrm{mm} \mathrm{cm}-1$ of soil); cc $_{c}$ is the moisture in the field capacity ( $\mathrm{m} 3 \mathrm{~m}-3$ of soil); ( $\mathrm{pmp}$ is the moisture at the permanent wilting

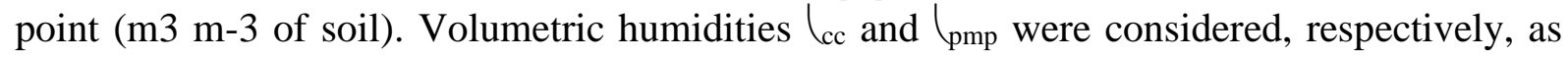
equivalent to soil matric potentials $100 \mathrm{hPa}$ and $15000 \mathrm{hPa}$ (Gomes, 2013). 
There was a linear correlation between TWA and CL, TS, and OC contents. Multiple linear regression TWA (CL, TS) was chosen, due to its simplicity and which also expressed adequate statistical indices in the analysis of variance.

The AWC is the product of the TWA by the effective depth $(\mathrm{Z})$ of the soybean root system, the latter being considered equal to $50 \mathrm{~cm}$, since it is in the range between 0.43 and $0.54 \mathrm{~m}$ defined by Bordin et al. (2008), evaluating different soil management systems and is below the depth attributed by Luján (1989). The soil AWC was mapped according to the Spline interpolator for Potential Regularisation.

\section{RESULTS}

The clay loam soils had a TWA of approximately $1.11 \mathrm{~mm} \mathrm{~cm}-1$, with a coefficient of variation (CV) around $15.14 \%$, while the TWA of the clay loam was around $1.53 \mathrm{~mm} \mathrm{~cm}-1$ of soil, for a CV of $10.98 \%$. These coefficients are considered small, according to the literature of Warrick and Nielsen (1980). For this same physical characteristic, Pereira et al. (2010) speculate a TWA between 1.2 and $1.6 \mathrm{~mm} \mathrm{~cm}-1$. The other error measures can be found in Table 1. This table also shows that CVs become relatively higher for the lowest averages of TWA. This finding agrees with several authors' estimates of moisture in different soils (Cichota and Lier, 2004).

Table 1. Analysis of variance of 157 samples made available by Embrapa in the Matopiba region.

\begin{tabular}{cccccc}
\hline Class (Name) & Class (abbr.) & TWA (Mean) & CV $(\boldsymbol{\%})$ & Maximum & Minimum \\
\hline Clay & Cl & 0.69 & 42.25 & 1.36 & 0.35 \\
Clay Loam & ClLo & 1.11 & 15.14 & 1.29 & 0.93 \\
Loam & Lo & 1.26 & 8.14 & 1.40 & 1.15 \\
Loamy Sand & LoSa & 0.56 & 66.25 & 1.07 & 0.09 \\
Sand & Sa & 0.47 & 43.49 & 0.72 & 0.19 \\
Sandy Clay & SaCl & 0.49 & 30.43 & 0.73 & 0.21 \\
Sandy Clay Loam & SaClLo & 0.73 & 24.83 & 1.08 & 0.21 \\
Sandy Loam & SaLo & 0.86 & 37.02 & 1.49 & 0.12 \\
Silty Clay & SiCl & 1.28 & 9.96 & 1.37 & 1.14 \\
Silty Clay Loam & SiClLo & 1.53 & 10.98 & 1.68 & 1.35 \\
\hline
\end{tabular}

The most recurrent texture in Embrapa's inventory of physical properties in the Matopiba complex (about 33.12\% of the sample) is sandy loam (Lumbreras, 2015). This textural taxonomy had $0.9 \mathrm{~mm} \mathrm{~cm}-1$ as the average available water. This class falls within the lower limit defined by Bernardo et al. (2006), in which the AW oscillates between 0.9 and $1.5 \mathrm{~mm}$ cm-1 in Brazilian soils.

These results induced the perception of a trend of linear increase of the TWA towards pedological classes with more concentrations of silt, as observed by Figure 2, where the isolates of water depths $(\mathrm{mm})$ per centimetre of soil grew in the direction of the vertex to the right of the textural triangle, which is significant for the silty textural class. Andrade and Stone (2011) found a positive correlation between the field capacity and the variables of silt and clay, which confirms the possibility of this graphical representation.

Equation A of the TWA (Table 2) with clay and sand obtained a mean error of $0.106 \mathrm{~mm}$ $\mathrm{cm}-1$ and a Root Mean Square Error (RMSE) of $0.145 \mathrm{~mm} \mathrm{~cm}-1$. These values reflect pedotransference functions with mean accuracy, since the coefficient of determination R2 was lower than 0.85 , according to the classification proposed by Reichert et al. (2020). Equation B had the advantage of prospecting the structural element organic carbon (OC). However, this variable under discussion did not correlate significantly with TWA. 
The RMSE (equivalent to $0.015 \mathrm{~m}^{3} \mathrm{~m}^{-3}$ ) is below some studies that estimated AW through parametric and non-parametric equations, such as PTF, based on neural networks, described by Haghverdi et al. (2018). They noticed a root mean square error of $0.033 \mathrm{~m} 3 \mathrm{~m}-3$, when evaluating as dependent variables the soil density, particle size, organic matter, and initial water content of the soils studied.
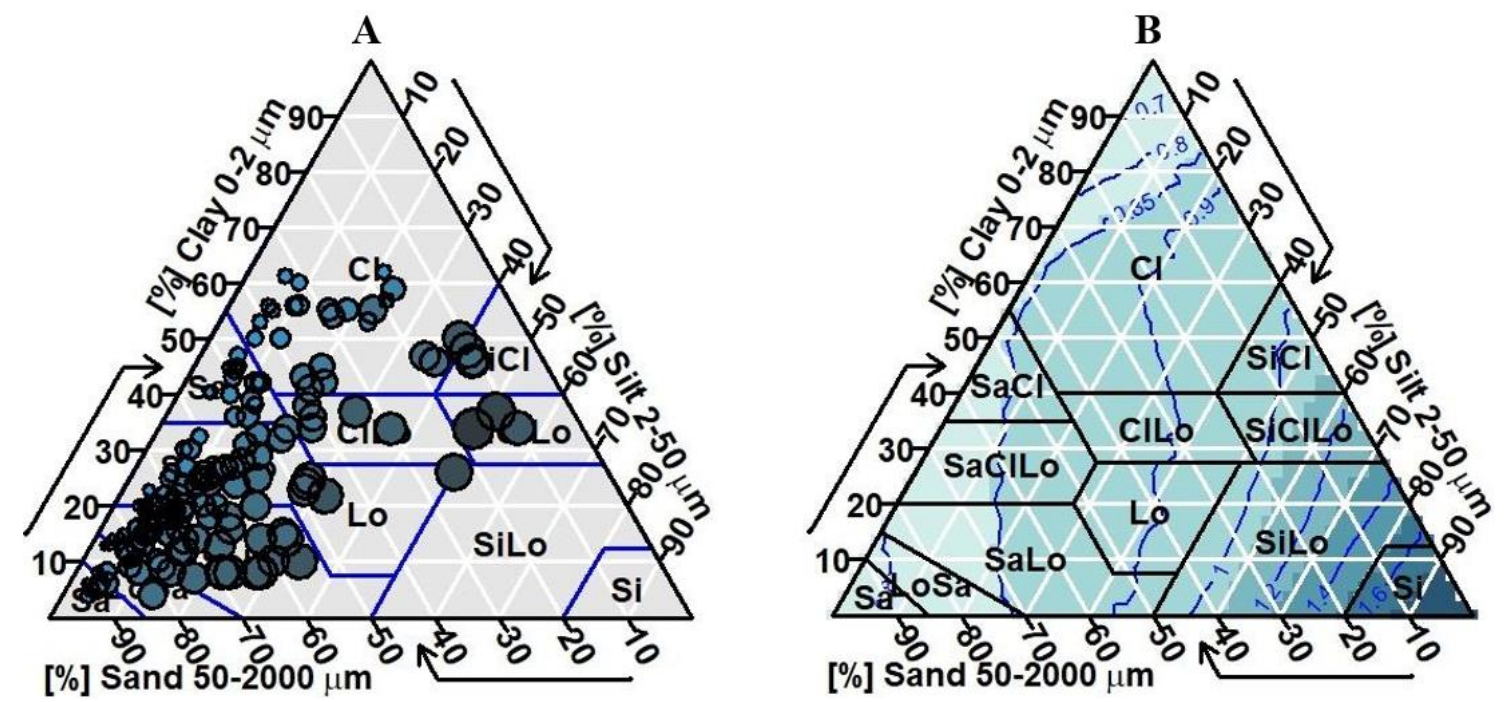

Figure 2. Textural triangles of 157 samples collected by Embrapa (A) and the water gradient available in the soil of Matopiba (B).

Table 2. Descriptive statistics of pedotransfer functions found for Matopiba that relate Total Water Availability (TWA) to the variables of Sand (TS), Clay (CL), Silt (ST), and Organic Carbon (OC).

\begin{tabular}{|c|c|c|c|c|c|c|}
\hline Equations & Variables & Coefficients & Test $t$ & $\mathbf{R} 2$ & EM & RMSE \\
\hline \multirow{3}{*}{ Equation A } & Independent & 3.2993 & $32.4685 * *$ & \multirow{3}{*}{0.80} & \multirow{3}{*}{0.106} & \multirow{3}{*}{0.145} \\
\hline & TS & -0.0028 & $-24.8135 * *$ & & & \\
\hline & $\mathrm{CL}$ & -0.0034 & $-23.0388 * *$ & & & \\
\hline \multirow{4}{*}{ Equation B } & Independent & 3.2589 & $30.9354 * *$ & \multirow{4}{*}{0.81} & \multirow{4}{*}{0.105} & \multirow{4}{*}{0.144} \\
\hline & TS & -0.0027 & $-24.0780 * *$ & & & \\
\hline & CL & -0.0034 & $-22.3672 * *$ & & & \\
\hline & OC & 0.0019 & 1.4023 & & & \\
\hline \multirow{3}{*}{ Equation $\mathrm{C}$} & Independent & -0.1400 & $-2.1747 *$ & \multirow{3}{*}{0.80} & \multirow{3}{*}{0.106} & \multirow{3}{*}{0.145} \\
\hline & $\mathrm{TS}$ & 0.0007 & $8.7822 * *$ & & & \\
\hline & ST & 0.0034 & $23.0388 * *$ & & & \\
\hline
\end{tabular}

ME: Mean Error in mm cm-1; RMSE: Root Mean Squared Error in mm cm-1; **: Significance at $1 \%$ by Student's t-test; *: $5 \%$ Significance at $5 \%$ by Student's t-test.

Equation A, in which TWA $=3.2993-0.0028 \mathrm{TS}-0.0034 \mathrm{CL}$, was chosen for the mapping of the AWC in the state of Tocantins (Figure 3). 


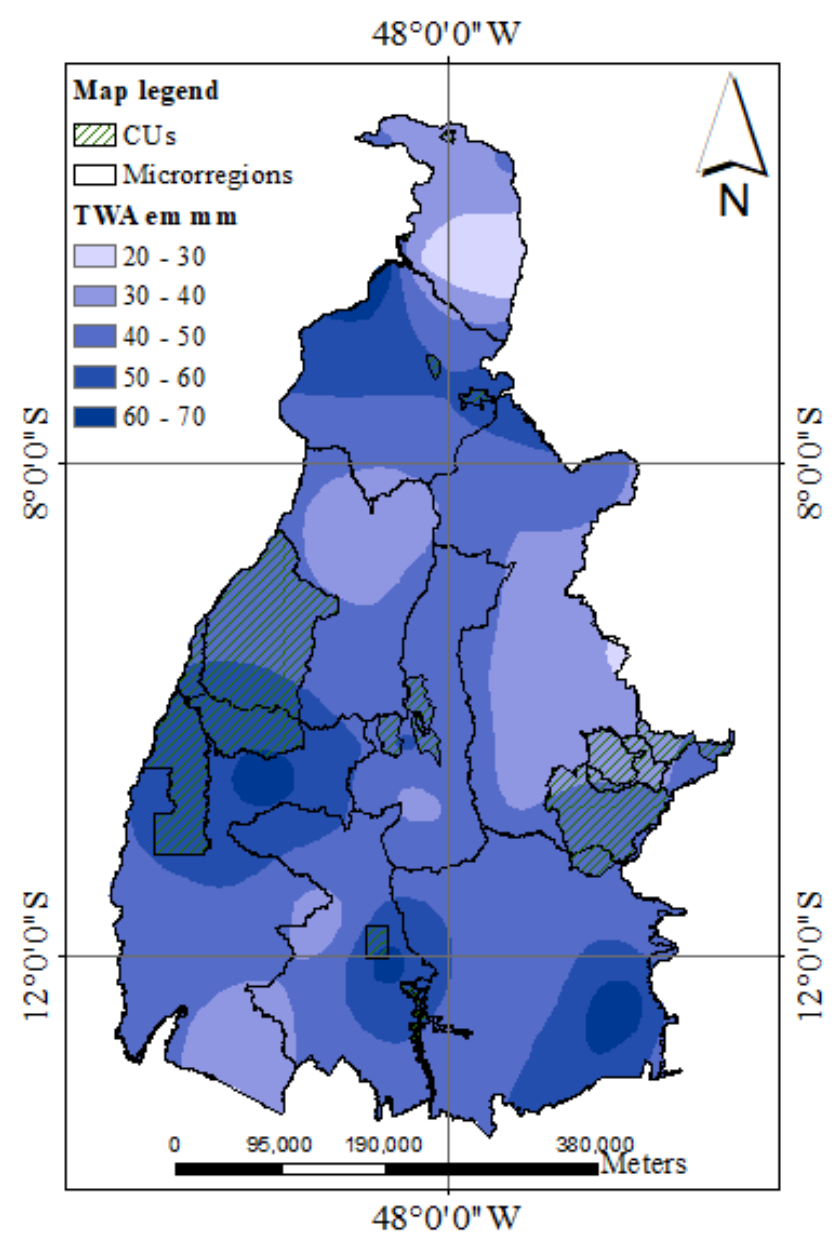

Figure 3. Distribution map of the values of Available Water Capacity (in $\mathrm{mm}$ ) for the soybean crop in the microregions of the state of Tocantins.

\section{DISCUSSION}

With the mapping of Figure 3, it was possible to observe a range of higher AWC values in the southwest of the state of Tocantins, in the Formoso River microregion, where part of the Environmental Protection Area (Área de Proteção Ambiental - APA) of Ilha do Bananal/Cantão is located. Based on this information, higher pressure from agribusiness around this Conservation Unit is expected in the near future. Currently, there are significant soybean occupancy rates in this protection area (Moreira and Collicchio, 2017).

However, according to the pedological survey, this region is composed of Plinthosols (Tocantins, 2012). Thus, the microregion of the Formoso River, with a plastic horizon, is a region of soils with low rainwater percolation and with a high probability of low growth of aerial and root mass in the vegetative development of soybeans in relation to other areas that do not have petroplintite concretions (Nikkel and Lima, 2019).

Various techniques can be used to favour the dynamics of water in the soil, such as scarification, to redefine the soil structure, its density and total porosity, as specified by Freitas et al. (2017). This can also be done with the control of organic matter used to stabilise soil architecture, as reported by Anjos et al. (2017), which justifies notable productions for this region due to the increase in water availability.

The map in detail thematises in the southern centre of the state a range of AWC values exceeding $60 \mathrm{~mm}$. Based on this elaborated matrix product alone, we believe that the State 
Environmental Protection Area Lago de Peixe-Angical may suffer pressure from the agricultural sector shortly, mainly exerted by soybean cultivation. However, the average annual rainfall distribution is $1,552.49 \mathrm{~mm}$, below the state average of $1,677 \mathrm{~mm}$ (Collicchio et al., 2015).

These rainfall indices indicate a likely lower relationship between actual and maximum evapotranspiration of a culture, despite an above-average AWC (greater than $50 \mathrm{~mm}$ ). Silva et al. (2020) ratify that water deficiency can affect leaf gas exchange (stomatal conductance, transpiration, etc.) and, consequently, the internal concentration of $\mathrm{CO} 2$ in plants, thus reducing the conditions necessary for root growth. We know that ten-year water balances could better validate this information.

It is noteworthy that Neosols are recurrent in the microregion of Jalapão (58.3\% of its area), located to the east of the state, in which $25,782 \mathrm{~km}^{2}$ of AWC were quantified, varying below the average between 30 and $40 \mathrm{~mm}$, more precisely in the municipality of Mateiros. The production and planted area of this municipality in 2019 allocated it as the third largest producer in the state (IBGE, 2019). In the same region and with the most extensive state productions, the municipality of Campos Lindos had a relatively regular AWC, between 40 and $50 \mathrm{~mm}$.

This latter situation may portray that water availability was higher due to management techniques adopted or because the arable areas of these units obtained a higher natural water supply. However, Melo et al. (2020) mapped the climatic risks for soybeans in the Brazilian Cerrado, considering the planting date on November 15 and AWC equal to $75 \mathrm{~mm}$, characterising only the municipal management of Campos Lindos as having a medium probability of water deficiency, that is, with higher chances of water deficit.

The regionalisation of the AWC indicates a development potential for the Dianópolis region, which is a strategic warehouse, given the logistics between the states of Bahia and Tocantins. It is also noteworthy that the municipality of Arraias, with no production history (IBGE, 2019), and Taguatinga obtained AWC values of approximately $65 \mathrm{~mm}$.

The AWC is a physical parameter that enhances, from a favourable rainfall regime, the water availability. Nevertheless, there are situations in which there are probabilities of water deficiency in precipitation above $800 \mathrm{~mm}$, which are optimal for their development, and with significant AWC. The range of moisture to be extracted by the species is dependent on the difference between $l_{c c}$ and $l_{\text {pmp }}$ when the soil has a favourable structure. However, soils with a density above $1.43 \mathrm{Mg} \mathrm{m}-{ }^{3}$ can be considered limiting factors for growth, aeration, and resistance to root penetration, as opposed to the favourable AWC (Rodrigues et al., 2017), which may explain the absence of productions in Dianópolis.

The microregion of Araguaína, especially the municipalities of Xambioá, Araguanã, Aragominas, Muricilândia, Santa Fé do Araguaia and Araguaína, obtained averages of available water from 50 to $60 \mathrm{~mm}$, higher than the state average. In some territories of these municipalities, these values exceeded $60 \mathrm{~mm}$. This political subdivision belongs to the Amazon biome and is entirely composed of Argisols. Prado (2018) noted that this soil taxonomy belongs to the class of available water greater than a range of soils studied, among them, the Neosols.

Regarding the mapping, Barca et al. (2019) evaluated the predictive efficiency of water content in the soil using the Ordinary Kriging (OK) and Kriging with External Drift (KED) methods in an experimental field in southeastern Italy. However, the pedotransfer functions correlated the soils' electrical conductivities, obtained by geophysical sensors, with the available water. KDE presented the best approximations between the estimated and observed values, which were subject to cross-validation. Therefore, we can assume that other methods may configure a better predictive capacity in areas not sampled in relation to the Linear Spline for Potential Regularisation, adopted in this study, provided that they take spatial variations into account as stochastic variables (Barca et al., 2019). 
This study emphasises the relevance of validating these sample data if there is any work that requires better state geographical detailing, municipal strategic planning that requires this variable (AWC) on more detailed scales, among other specific studies that contribute to the sustainable development of agribusiness.

\section{CONCLUSIONS}

The lowest averages of TWA meant higher CV values when statistically analysing 157 granulometric samples, a result measured by other authors. The pedotransference function selected, which related the clay and sand contents with the TWA, was Equation A in Table 2. From this parameterisation, the mapping of the AWC suggested a scenario of possible evasion of soybeans in the Jalapão microregion, especially in the municipality of Campos Lindos, one of the protagonists of agroindustrial logistics of Matopiba.

In the state of Tocantins, we identified that the Formoso River microregion, which produces soybeans, had the highest amount of water available per centimetre of soil for agricultural consumption and annual average rainfall above the state average. This scenario may consolidate the threats diagnosed by other authors to the APA of Ilha do Bananal/Cantão. The pressure exerted by soybean cultivation on the agricultural sector in this CU was validated by the high grain production found in the region.

To verify this last hypothesis, further studies could measure the water balance of this oilseed to estimate the distribution of relative water deficiencies in a given time interval numerically, with a minimum of 15 years of rainfall and temperature data observed. The experimental validation of Equation A in Table 2 is also necessary for local technical studies of this variable.

\section{REFERENCES}

ANDRADE, R. da S.; STONE, L.F. Estimativa da umidade na capacidade de campo em solos sob cerrado. Revista Brasileira de Engenharia Agrícola e Ambiental, v.15, n.2, p.111116, 2011. https://doi.org/10.1590/S1415-43662011000200001

ANJOS, J. C. R.; ANDRADE JÚNIOR, A. S.; BASTOS, E. A.; NOLETO, D. H.; MELO, F. B.; BRITO, R. R. Armazenamento de água em Plintossolo Argilúvico cultivado com cana de açúcar sob níveis de palhada. Pesquisa Agropecuária Brasileira, v. 52, n. 6, p. 464473, 2017. https://doi.org/10.1590/S0100-204X2017000600010

ARYA, L. M.; PARIS, J. F. A physico empirical model to predict soil moisture characteristics from particle-size distribution and bulk density data. Soil Science Society of America $\begin{array}{llllll}\text { Journal, } & \text { v. } & 45, & \text { n. } & 6, & \text { p.1023-1030, }\end{array}$ https://doi.org/10.2136/sssaj1981.03615995004500060004x

BARCA, E.; De BENEDETTO, D.; STELlACCI, A. M. Contribution of EMI and GPR proximal sensing data in soil water content assessment by using linear mixed effects models and geostatistical approaches. Geoderma, 343, 280-293, 2019. https://doi.org/10.1016/j.geoderma.2019.01.030

BERnARDO, S.; SOARES, A. A.; MANTOVANI, E. C. Manual de Irrigação. Viçosa: Imprensa Universitária da UFV, 2006.

BORDIN, I.; NEVES, C. S. V. J.; MEDINA, C. C.; SANTOS, J. C. F.; TORRES, E.; URQUIAGA, S. Matéria seca, carbono e nitrogênio de raízes de soja e milho em plantio direto e convencional. Pesquisa Agropecuária Brasileira, v. 43, n. 12, p. 1785-1792, 2008. https://doi.org/10.1590/S0100-204X2008001200020 
BRUNING, J.; ROBAINA, A. D.; PEITER, M. X.; BOSCAINI, R.; CONCEIÇÃO, C. G.; GOLLO, E. A. Estimativa da curva de retenção de água no solo por função de pedotransferência. Revista Cultura Agronômica, v. 28, n. 1, p. 97-110, 2019. http://dx.doi.org/10.32929/2446-8355.2019v28n1p97-110

CICHOTA, R.; VAN LIER, Q. J. Análise da variabilidade espacial de pontos amostrais da curva de retenção da água no solo. Revista Brasileira de Ciência do Solo, v. 28, n. 4, p. 585-596. 2004. https://doi.org/10.1590/S0100-06832004000400001

COLLICCHIO, E.; ROCHA, H. R.; VICTORIA, D. C.; BALLESTER, M. V. R.; TOLEDO, A. M. A. Implicações das mudanças do clima no zoneamento agroclimático da cana-deaçúcar no Estado de Tocantins, considerando o modelo GFDL. Revista Brasileira de Geografia Física, v. 08, n. 06, p. 1730-1747, 2015.

EMBRAPA. Centro Nacional de Pesquisa de Solos. Sistema brasileiro de classificação de solos. Brasília: Embrapa -SPI; Rio de Janeiro: Embrapa Solos, 2018. 355p.

EMBRAPA. Sistema de Informação de Solos Brasileiros da EMBRAPA. Available: http://www.sisolos.cnptia.embrapa.br. Access: 25 Dec. 2020.

FREITAS, L. A MELlO, L. M. M.; ANDREOTTI, M.; YANO, É. H.; SOARES, D. A.; PEREIRA, D. S. Soil physical and phenological attributes of soybean in different management systems and gypsum. Revista Brasileira de Ciências Agrárias, v. 12, n. 4 , p. 508-515, 2017.

GOMES, H. P. Sistemas de irrigação: eficiência energética. João Pessoa: Editora da UFPB, 2013.281p.

HAGHVERD, A.; ÖZTÜRK, H. S.; DURNER, W. Measurement and estimation of the soil water retention curve using evaporation method and pseudo continuous pedotransfer $\begin{array}{llllll}\text { function. Journal of Hydrology, v. 563, p.251-259, } 2018 . & \end{array}$ https://doi.org/10.1016/j.jhydrol.2018.06.007

IBGE. Produção agrícola municipal, culturas temporárias e permanentes, 2019. Rio de Janeiro, 2019. Available: https://sidra.ibge.gov.br/pesquisa/pam/tabelas. Access: 06 Nov. 2020

LEMOS, M. L. F.; GUIMARÃES, D. D.; MAIA, G. B. S.; AMARAL, G. F. Agregação de valor na cadeia da soja. Agroindústria - BNDES Setorial, v. 46, n. 1, p. 167-217, 2017.

LIMA, A. M. N.; PELÚZIO, J. M.; SIQUEIRA, F. L. T.; OLIVEIRA JÚNIOR, W. P. Efeito do déficit hídrico e época de semeadura sobre os teores e rendimentos de óleo e proteína em cultivares de soja no Tocantins. Revista de La Facultad de Agronomía, v. 116, n. 2, p. 193-199, 2017.

LUJÁN, J. G. Riego por aspersión. Madrid: Centro de Estudios Hidrográficos, CEDEX/MOPU, 1989.

LUMBRERAS, J. F. et al. Aptidão agrícola das terras do Matopiba. Rio de Janeiro: Embrapa Solos, 2015. 48 p.

MELO, A. C. A.; NOBRE JÚNIOR, A. A.; SILVA, F. A. M.; ABREU, L. M. Zoneamento de risco climático para cultivo da soja no Cerrado. Revista Nativa, v. 8, n. 1, p.26-36, 2020. https://doi.org/10.31413/nativa.v8i1.8249 
MORANDO, R.; SILVA, A. O.; CARVALHO, L. C.; PINHEIRO, M. Déficit hídrico: efeito sobre a cultura da soja. Journal of Agronomic Sciences, v. 3, n. especial, p. 114-129, 2014.

MOREIRA, D. C.; COLLICCHIO, E. Prerrogativas da legislação ambiental estadual em relação à APA Ilha do Bananal/Cantão. Revista Liberato, v. 18, p. 197-211, 2017.

NIKKEL, M.; LIMA, S. O. Growth and vegetative development of soybean plants in soil type concrectionary petric plinthosol. Scientia Agraria Paranaensis, v. 18, n. 4, p. 351-356, 2019. https://doi.org/10.18188/sap.v18i4.22452

PEREIRA, L. S.; VALERO, J. A. de J.; BUENDÍA, M. R. P.; MARTÍN-BENITO, J.M.T. El riego y sus tecnologías. Albacete: CREA-UCLM, 2010. 296 p.

PRADO, H. do. Pedologia fácil. [S.1.]: do Autor, 2018.

PREVEDELLO, C. L.; ARMINDO, R. A. Física do solo com problemas resolvidos. 2. ed. Curitiba: Do Autor, 2015. 474p.

REICHERT, J. M.; ALBUQUERQUE, J. A.; PERAZA, J. E. S.; COSTA, A. Estimating water retention and availability in cultivated soils of southern Brazil. Geoderma Regional, v. 21, n. 277, p. 1-12, 2020. https://doi.org/10.1016/j.geodrs.2020.e00277

RODRIGUES, T. R.; CASAROLI, D.; EVANGELISTA, A. W. P.; ALVES JÚNIOR, J. Water availability to soybean crop as a function of the least limiting water range and evapotranspiration. Pesquisa Agropecuária Tropical, v. 47, n.2, p.161-167, 2017. https://doi.org/10.1590/1983-40632016v4743746

SANTOS, W; G.; MARTINS, J. I. F. O Zoneamento Agrícola de Risco Climático e sua contribuição à agricultura brasileira. Revista de Política Agrícola, v. 25, n. 3, p.73-94, 2016.

SILVA, J. A.; SANTOS, P. A. B.; CARVALHO, L. G.; MOURA, E. G.; ANDRADE, F. R. Gas exchanges and growth of soybean cultivars submitted to water deficiency. Pesquisa Agropecuária Tropical, v. 50, e58854, p. 1-9, 2020. https://doi.org/10.1590/198340632020v5058854

TOCANTINS. Secretaria do Planejamento do Estado do Tocantins (Seplan). Base de dados geográficos do Tocantins - atualização 2012. Palmas: Seplan, 2012 (Base de Dados Geográficos).

TOMASElLA, J.; HOODNETT, M. G.; ROSSATO, L. Pedotransfer functions for the estimation of soil water retention in Brazilian soils. Soil Science Society America Journal, v. 64, p. 327-338, 2000. https://doi.org/10.2136/sssaj2000.641327x

VAN GENUCHTEN, M. Th. A closed-form equation for predicting the hydraulic conductivity of unsaturated soils. Soil Science Society of America Journal, v. 44, n. 5, p. 892-898, 1980. https://doi.org/10.2136/sssaj1980.03615995004400050002x

VAZ, C. M. P.; IOSSI, M. F.; NAIME, J. M.; MACEDO, A. Validação de modelos para estimativa indireta da capacidade de retenção da água nos solos. São Carlos: Embrapa Instrumentação Agropecuária, 2004.

VIANA J. H. M., TEIXERIRA, W. G.; DONAGEMMA G. K. Manual de métodos de análise de solo. 3. ed. Brasília, DF: Embrapa, 2017. 573 p. 
WARRICK, A. W.; NIELSEN, D. R. Spatial variability of soil physical properties in the field. In: HILLEL, D. (ed.) Applications of soil physics. New York: Academic Press, 1980. p.319-344.

ZANON, A. J.; SILVA, M. R.; TAGLIAPIETRA, E. L.; CERA, J. C.; BEXAIRA, K. P.; RICHTER, G. L. et al. Ecofisiologia da soja visando altas produtividades. Santa Maria: UFSM, 2018. 136 p. 